\title{
Foetal phenotype of Maat-Kievit-Brunner type Ohdo syndrome
}

Gupta Ashutosh 1*, Aneja Anjila ${ }^{2}$, Bahl Neena ${ }^{3}$, Arora Rupam ${ }^{4}$, Sehgal Renu Raina ${ }^{\text {, }}$, Saini Pankaj ${ }^{6}$

${ }^{1}$ MBBS, MS (OBGYN), DM (Medical Genetics), Foetal Medicine \& Medical Geneticist, Artemis Hospitals, Gurgaon, India.

${ }^{2}$ MBBS, MD (PGI), MRCOG, FRCOG, Diploma in Pelvic Endoscopy, Department of Minimal Access Surgery (Gynaecology), Fortis Memorial

Research Institute, Gurgaon.

${ }^{3}$ MBBS, MD (Obst \& Gynae), Department of Minimal Access Surgery (Gynaecology), Fortis Memorial Research Institute, Gurgaon.

${ }^{4} \mathrm{MBBS}, \mathrm{MS}$ (Obst \& Gynae), Department of Obstetrics \& Gynecology, Artemis Health Institute, India.

${ }^{5}$ MBBS, DNB (Obst \& Gynae), MNAMS, Department of Obstetrics \& Gynecology, Artemis Health Institute, India.

${ }^{6} \mathrm{MBBS}, \mathrm{MD}$ (Radiodiagnosis), Department of Radiology, Manipal Hospitals, Dwarka, India.

Corresponding Author: Gupta Ashutosh, MBBS, MS (OBGYN), DM (Medical Genetics), Foetal Medicine \& Medical Geneticist, Artemis Hospitals, Gurgaon, India.

Received Date: June 02, 2021; Accepted Date: September 10 2021; Published Date: September 252021

Citation: Gupta Ashutosh, Aneja Anjila, Bahl Neena, Arora Rupam, Sehgal Renu Raina, Saini Pankaj (2021) Foetal phenotype of Maat-KievitBrunner type Ohdo syndrome. Clinical Medical Reviews and Reports. 3(8); DOI: 10.31579/2690-8794/088

Copyright: (C) 2021, Gupta Ashutosh, This is an open access article distributed under the Creative Commons Attribution License, which permits unrestricted use, distribution, and reproduction in any medium, provided the original work is properly cited.

\begin{abstract}
MED12 is a member of large Mediator complex; has a very crucial and central role in RNA polymerase II transcription; regulating cell signals involved in growth, development and differentiation.

Different MED12 mutations may have different clinical presentation representing an allelic disorder.

Maat-Kievit-Brunner (MKB) type Ohdo syndrome; has a typical facial features comprising of blepharophimosis, ptosis, long flat philtrum with thin vermilion, micrognathia with microstomia, scrotal hypoplasia with cryptorchidism, joint hypermobility with clinodactyly with overriding toes,

A primigravida on antenatal ultrasound was detected to have growth restriction, corpus callosal dysgenesis, syndactyly and suspected ambiguous genitalia. Invasive testing and exome sequencing revealed hg 19chrX:MED12:c.2315A>G: (p.Lys772Arg);MED12(NM_005120.3):c.2315A>G: (p.Lys772Arg) leading to provisional diagnosis of X linked Ohdo syndrome with an overlap with FG. Missense mutation was classified to be PM2; PP3 (ACMG)

Clinical presentation, phenotype and mutational analysis led to provisional diagnosis of X linked Ohdo syndrome. Maat-KievitBrunner type of Ohdo syndrome is a rare condition and this is probably the first case describing foetal phenotype of MKB type of Ohdo syndrome.

Key words: med12; allelic; mkb, ohdo syndrome; micrognathia; cryptorchidism; blepharophimosis; philtrum; vermilion, foetal; maat-kievit-brunner (mkb) type ohdo syndrome; blepharophimosis-mental retardation syndrome; $\mathrm{x}$ linked ohdo syndrome
\end{abstract}

\section{Introduction}

In 1974, Opitz and Kaveggia described a X-linked recessive intellectual disability syndrome characterized by relative macrocephaly, hypertelorism, downslant palpebral fissures, prominent forehead with frontal hair upsweep with broad thumbs and halluces [1].

In 1984, Lujan et al reported four male patients with marfanoid habitus, long narrow face, small mandible with high-arched palate, hypernasal voice with intellectual disability [2].
In 1993, Maat-Kievit et al delineated a X-linked Ohdo syndrome; characterized by failure to thrive with facial features comprising blepharophimosis, ptosis, wide depressed nasal bridge, long philtrum, thin vermilion, micrognathia with microstomia, scrotum hypoplasia with cryptorchidism, joint hypermobility, overriding toes with clinodactyly, cafe-au-lait spots, developmental delay with hearing disability [3].

In 2007, Risheg et al documented a recurrent MED12 mutation (p.Arg961Trp) which was earlier diagnosed as FG (Opitz-Kaveggia) 
syndrome [5]. Reported a different mutation (p.Gly958Glu) with similar clinical phenotype [4]. Demonstrated (p.Asn1007Ser) MED12 mutation in a family originally diagnosed as Lujan-Fryns syndrome [6].

Vulto-van Silfhout [11] reported (p.Arg1148His, p.Ser1165Pro and p.His1729Asn) mutations in a family originally documented as MKB. [7]

\begin{tabular}{|c|c|c|}
\hline FG syndrome type 1 (FGS1) & Lujan syndrome (LS) & X-linked Ohdo syndrome \\
\hline \multicolumn{3}{|l|}{ Craniofacial } \\
\hline \multicolumn{3}{|l|}{ Growth } \\
\hline $\begin{array}{l}\text { Absolute or relative macrocephaly, normal } \\
\text { height to short stature }\end{array}$ & $\begin{array}{l}\text { Large head circumference ( }>75 \text { th } \\
\text { centile); typically tall, thin built with } \\
\text { height (> 75th centile). Marfanoid } \\
\text { habitus. }\end{array}$ & Normal growth to short stature to growth failure \\
\hline \multicolumn{3}{|l|}{ Central nervous system } \\
\hline \multicolumn{3}{|l|}{ Genitourinary } \\
\hline Cryptorchidism and inguinal hernia & Small testes, large testes, and varicoceles & Cryptorchidism, small penis, and shawl scrotum \\
\hline \multicolumn{3}{|c|}{ Present Case } \\
\hline Established feature & Identified Antenatally (Fig 1) & Identified Postnatally (Fig 2) \\
\hline Cryptorchidism, Scrotal hypoplasia & Ambiguous genitalia & Penoscrotal hypospadias \\
\hline Clinodactyly, Overriding 3rd toes & Syndactyly $2 \& 3^{\text {rd }}$ toe, single feet & Confirmed \\
\hline Low weight & Early onset growth retardation & \\
\hline $\begin{array}{l}\text { Blepharophimosis, Ptosis, Wide nasal bridge, } \\
\text { Depressed nasal bridge, Large nose, Bulbous } \\
\text { nose, Long philtrum, Flat philtrum, Thin } \\
\text { vermilion }\end{array}$ & & $\begin{array}{l}\text { Blepharophimosis, low set ears, thin vermilion, } \\
\text { long philtrum }\end{array}$ \\
\hline
\end{tabular}

Maat-Kievit-Brunner (MKB) type Ohdo syndrome has a X-linked recessive inheritance pattern with typical facial features like thick alae nasi, blepharophimosis, ptosis, wide depressed nasal bridge, large bulbous nose, long flat philtrum with thin vermilion, micrognathia with microstomia, feeding difficulties, scrotal hypoplasia with cryptorchidism, joint hypermobility with clinodactyly with overriding toes, cafe-au-lait spots, hearing disability. Facial features become more pronounced with age with characteristic triangular facies [1]. It may have mild to severe developmental delay with delayed motor milestones with behavioural problems with mental retardation.
Isidor et al. identified (p.Arg1148His) mutation in two male siblings with phenotype similar to those of MKB [8].

It is now established that MED12 mutations have different clinical presentation representing an allelic disorder. (Table 1) [9].

\section{Table 1 -Characteristics Features of allelic disorders; FGS1, LS, Ohdo syndrome and Foetal features which were identified Antenatally and \\ Postnatally
Polle 1 -Characteristics Features of allelic disorders, F GSI, LS, Ohdo synd}

Maat-Kievit-Brunner type of Ohdo syndrome is a rare condition and this is probably the first case describing foetal phenotype of MKB type of Ohdo syndrome. It is caused MED12 gene (mediator complex subunit 12) mutations; which is a subunit of the mediator complex, a group of about 25 proteins which regulates gene activity. It physically links transcription factors to turn on or off the genes. MED12 protein is involved in development of the neurons, in several chemical signalling pathways to regulate cell growth, migration and differentiation. 


\section{Case Report}

A booked primigravida at 19 weeks of pregnancy with no high risk factor was evaluated in the department of Foetal Medicine at Artemis Hospital for foetal anomaly scan. It is a non-consanguineous marriage and no other male member of the extended family has been affected with intellectual disability or dysmorphism.
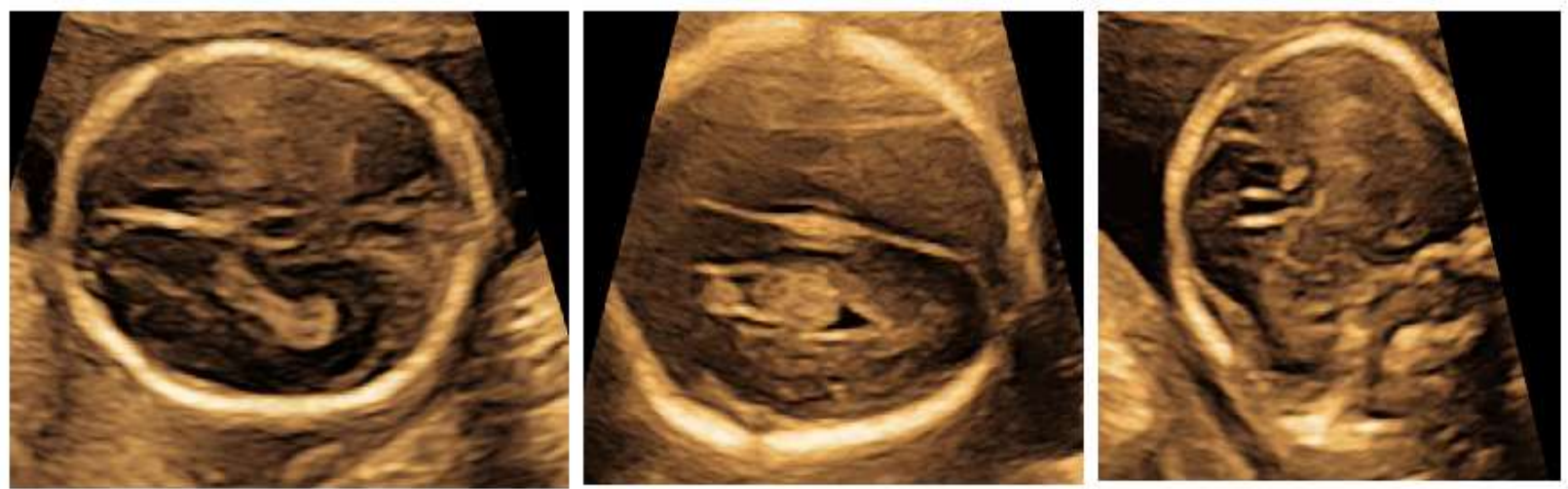

(a)
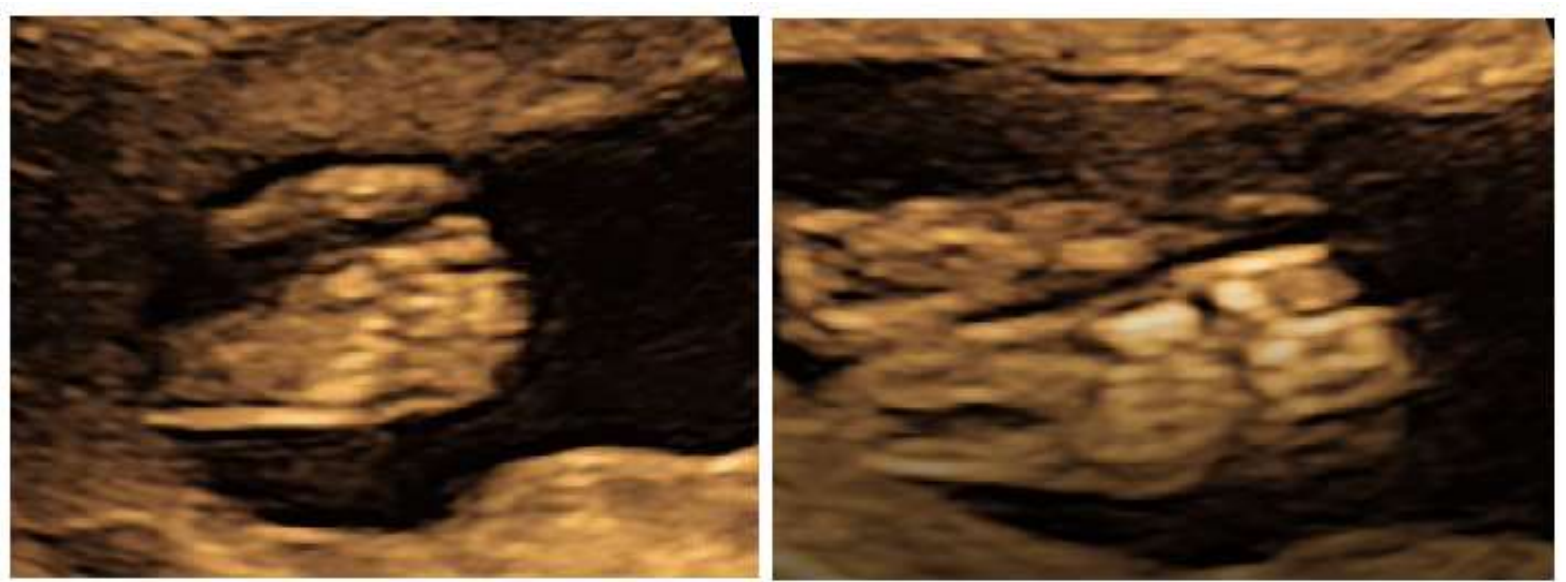

Picture demonstrating syndactyly of $2 \& 3$ toes (b)
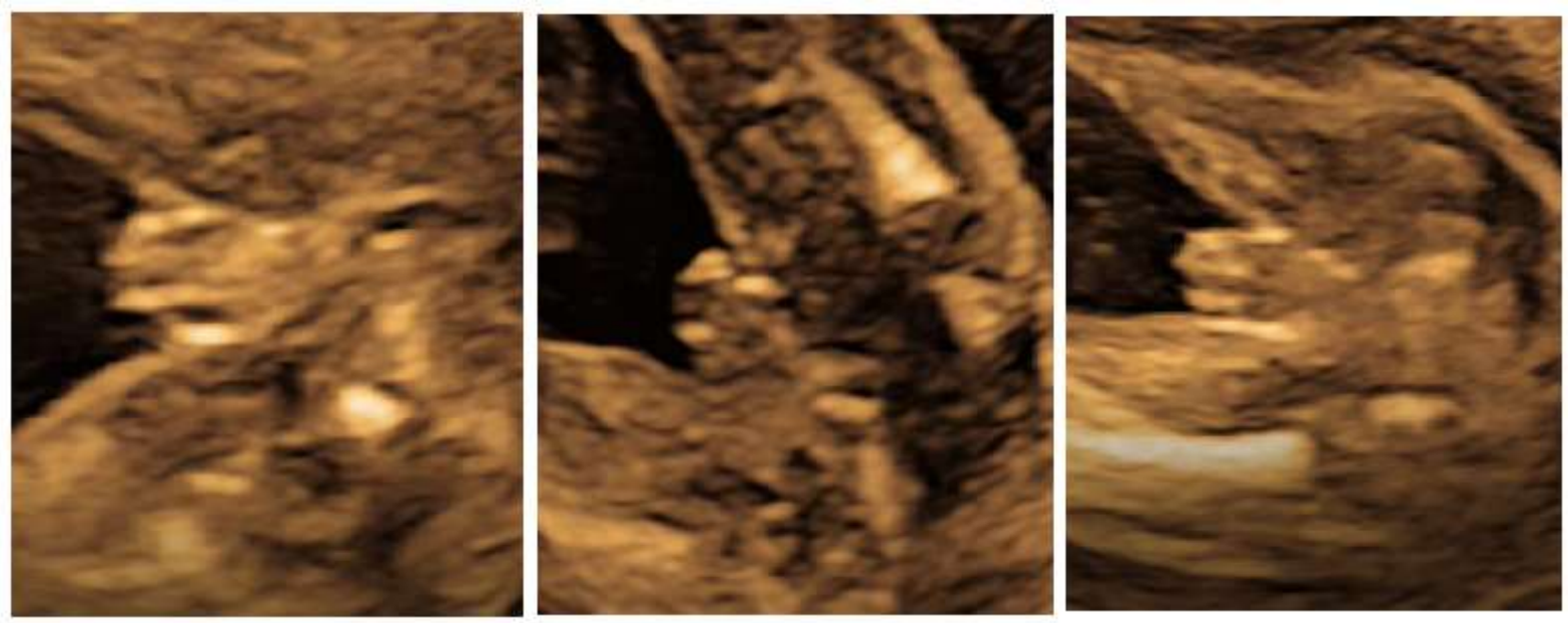

Ultrasound pictures depicting ambiguous genitalia / Sex reversal (c) 


\begin{tabular}{|c|c|c|c|c|c|c|c|c|c|c|}
\hline LMP 06 & \multirow{2}{*}{06.112019} & GALMP] & 19w2d & \multirow{2}{*}{\multicolumn{2}{|c|}{$\begin{array}{l}\text { EODILMP) } \\
\text { EODIAUA }\end{array}$}} & \multirow{2}{*}{\multicolumn{2}{|c|}{$\begin{array}{l}12.032020 \\
20.03 .2020\end{array}$}} & \multirow{2}{*}{$\begin{array}{l}\mathrm{G} \\
\mathrm{P}\end{array}$} & \multirow[t]{2}{*}{1} & \multirow{2}{*}{$\begin{array}{l}A b \\
\text { Ec }\end{array}$} \\
\hline Doc & & GARAUA] & 18w1d & & & & & & & \\
\hline \multicolumn{2}{|l|}{ EFW Hodiock } & \multirow{2}{*}{$\begin{array}{l}\text { Value } \\
22200\end{array}$} & \multirow{2}{*}{\multicolumn{2}{|c|}{$\begin{array}{l}\text { Ronge } \\
\pm 329\end{array}$}} & \multirow{2}{*}{$\begin{array}{l}\text { Age: } \\
\text { 18wOd }\end{array}$} & \multirow{2}{*}{\multicolumn{2}{|c|}{ Range }} & \multirow[t]{2}{*}{$G P$} & \multicolumn{2}{|c|}{ Willems } \\
\hline AC/BPD/FU/HC & & & & & & & & & & $N / A$ \\
\hline 20 Meosurements & $A \cup A$ & velue & $m 1$ & $m z$ & & n3 & Math. & GP & & Age \\
\hline BPD (Hodlock) & 8 & $3.96 \mathrm{~cm}$ & 3.96 & & & & avg: & $1,+1$ & $76 \%$ & 18 wod \\
\hline OFO IHCI & & $5.29 \mathrm{~cm}$ & 5.29 & & & & oug & & & \\
\hline HC(Hadloch) & R & $15.17 \mathrm{~cm}$ & 15.17 & & & & avg. & $1+1-1$ & $5.4 \%$ & 18 wed \\
\hline HCF (Madlock) & 를 & $14.63 \mathrm{~cm}$ & 14.63 & & & & & +1 & $16 \%$ & $17 w 6 d$ \\
\hline AC(Hodlocky & e & $12.50 \mathrm{~cm}$ & 1250 & & & & क्र० & $\because+4$ & $12.6 \%$ & 18 wid \\
\hline FL Hadlock\} & e & $2.62 \mathrm{~cm}$ & $\cdot$ & 2.62 & & & ovg. & $1+1=$ & $7.1 \%$ & 18wad \\
\hline
\end{tabular}

Antenatal ultrasound depicting growth restriction (d)

Figure 1 - Antenatal examination of the foetus

Axial scan of foetal brain showing high riding $3^{\text {rd }}$ ventricle; upward displacement of the third ventricle; increased separation of the hemispheres, Coronal scan of a normal foetal brain demonstrating absence of the corpus callosum (genu), an increased distance between the frontal horns and their abnormal aspect suggestive of corpus callosal dysgenesis (a)

In the advent of foetal growth restriction, corpus callosal dysgenesis, syndactyly and suspected ambiguous genitalia; the consult and (parents) was counselled for invasive foetal testing; amniocentesis was done and on exclusion of maternal cell contamination; foetal DNA was processed for exome sequencing. Ambiguous genitalia in the clinical picture prompted and pointed towards foetal cholesterol pathway defect thus an
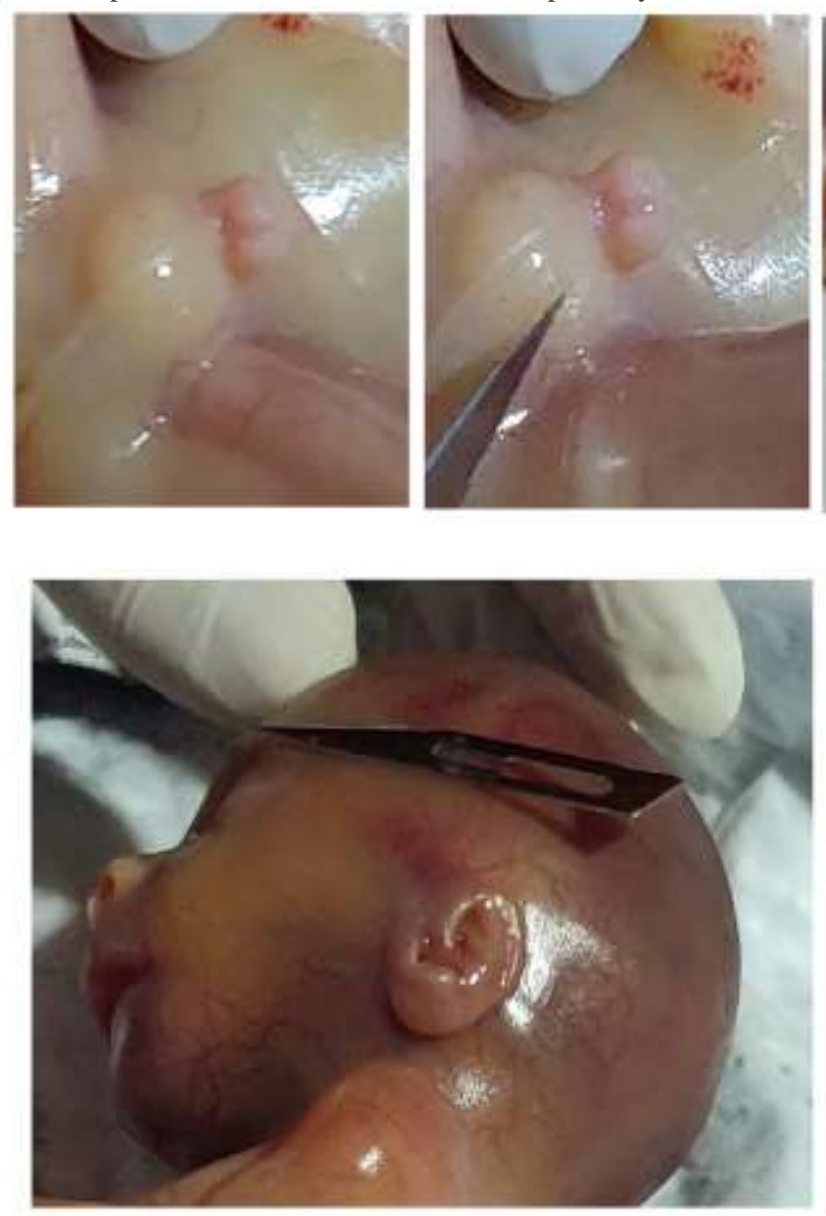

exome sequencing was ordered. With all this information, possibilities couple decided for an irreversible decision regarding the pregnancy.

Postnatal examination of the foetus showed penoscrotal hypospadias, syndactyly in $2 \& 3^{\text {rd }}$ toe in the right feet and normally separated 2 and $3^{\text {rd }}$ toe in the left toe (Figure 2-a) corroborating the main antenatal findings. It also revealed bilateral low set ears, micrognathia (Figure 2-b), thin vermilion, long philtrum and blepharophimosis (bilateral and both eye lids could not be separated completely with considerable effort) (Figure 2-c) corroborating the diagnosis of $\mathrm{X}$ linked Ohdo syndrome. The consult and (parents) gently refused for further postnatal (post mortem) examination of the foetus.

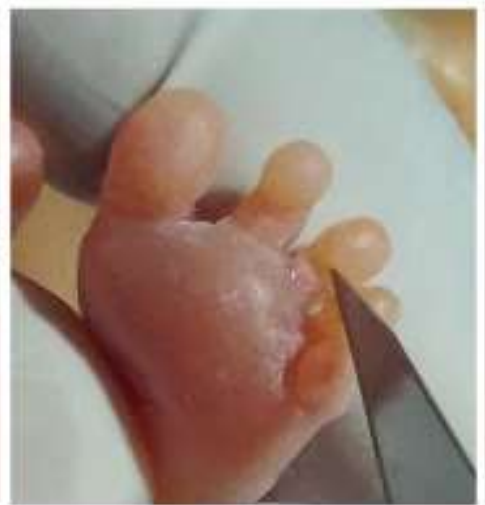

(a)

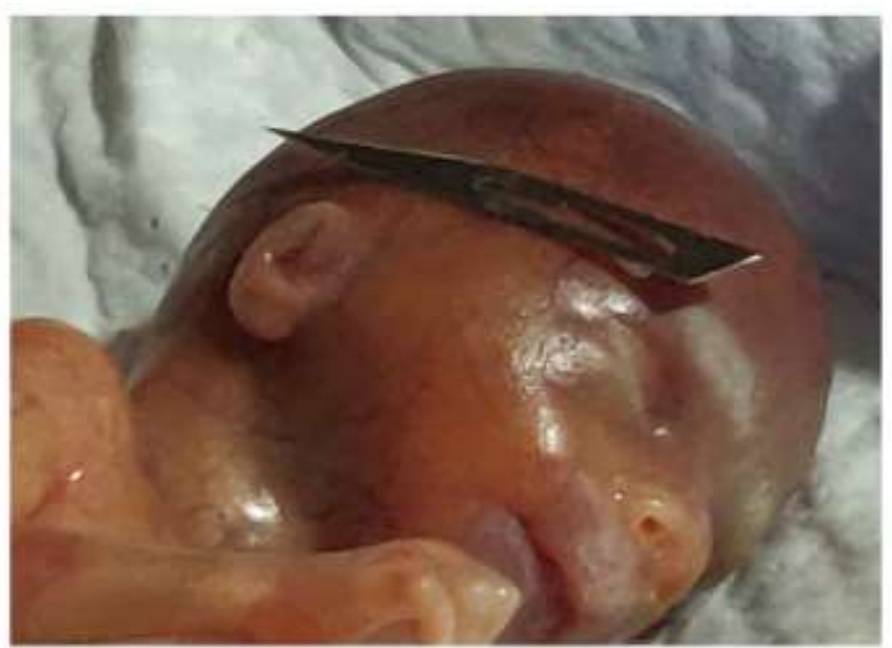

(b) 

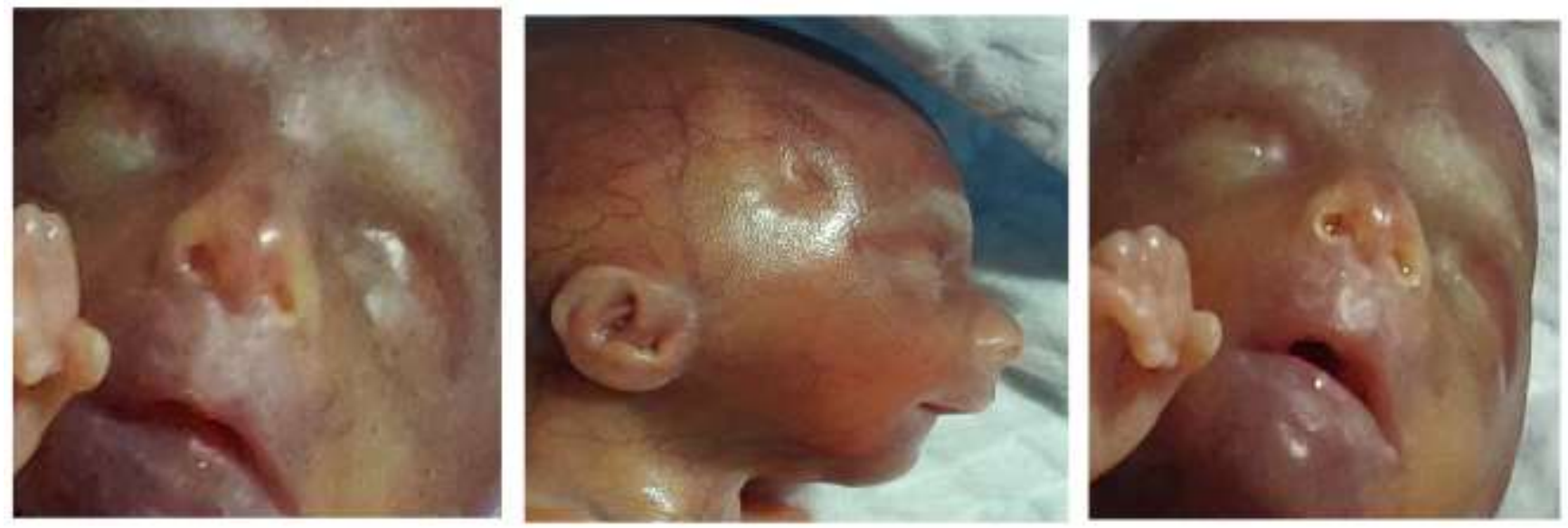

(c)

Figure 2 - Postnatal examination of the foetus showing penoscrotal hypospadias, syndactyly in $2 \& 3 r d$ toe in right feet versus normal $2 \& 3 r d$ toe in left toe (a), bilateral low set ears, micrognathia (b), blepharophimosis, thin vermilion and long philtrum (c).

Exome sequencing revealed hemizygous missense variation singlenucleotide variant (SNV) in exon 16 of the MED12 gene (Xq13.1); with amino acid substitution of Arginine for Lysine at codon 772, c.2315A>G (p.Lys772Arg); $\quad$ hg19chrX:MED12:c.2315A>G:(p.Lys772Arg); MED12(NM_005120.3):c.2315A>G:(p.Lys772Arg) leading to provisional diagnosis of possible $M E D 12$ related disorder; X linked Ohdo syndrome or FG syndrome.

The same mutation was confirmed by sanger sequencing and identified in the asymptomatic mother. In silico prediction of the variant has been identified to be damaging by LRT and Mutaion Taster.

In accordance to the American College of Medical Genetics and Genomics (ACMG) criteria for classifying pathogenic variants; the variation was classified as variant of uncertain significance and the missense mutation was classified to be PM2 (absent from controls or at extremely low frequency if recessive) and PP3 (multiple lines of computational evidence support a deleterious effect on the gene or gene product). (19)

Table no 1 elaborates characteristic features of the Ohdo syndrome; some of which detected antenatally were confirmed and remaining were identified by postnatal examination. Maat-Kievit et al. (1993), Verloes et al. (2006) and Vulto-van Silfhout et al. (2013) (3, 7, 14) have reported missense mutations in MED 12 to be causative for Maat-Kievit-Brunner type Ohdo syndrome (Table 2). Table no 3 describes the genotype phenotype corelation of MED 12 mutations.

\begin{tabular}{|c|c|c|c|c|c|}
\hline No of subjects & Type of mutation & Mutation & PolyPhen-2 (9) & SIFT (10) & Authors \\
\hline 2 males; postnatal & $\begin{array}{l}\text { hemizygous c.3443G- } \\
\text { A missense }\end{array}$ & $\begin{array}{l}\text { arg1148-to-his } \\
(\mathrm{R} 1148 \mathrm{H})\end{array}$ & $\begin{array}{l}\text { probably } \\
\text { damaging }\end{array}$ & deleterious & $\begin{array}{l}\text { Maat-Kievit et al. } \\
\text { (1993) (3) }\end{array}$ \\
\hline 2 males; postnatal & $\begin{array}{l}\text { hemizygous c.3493T- } \\
\text { C missence }\end{array}$ & ser1165-to-pro (S1165P) & $\begin{array}{l}\text { probably } \\
\text { damaging }\end{array}$ & deleterious & $\begin{array}{l}\text { Verloes et al. } \\
\text { (2006) (14) }\end{array}$ \\
\hline $\begin{array}{l}9 \text { simplex male; } \\
\text { postnatal }\end{array}$ & $\begin{array}{l}\text { hemizygous de novo } \\
\text { c. } 5185 \mathrm{C}-\mathrm{A} \\
\text { transversion }\end{array}$ & $\begin{array}{l}\text { his1729-to-asn } \\
(\mathrm{H} 1729 \mathrm{~N})\end{array}$ & $\begin{array}{l}\text { probably } \\
\text { damaging }\end{array}$ & deleterious & $\begin{array}{l}\text { Vulto-van Silfhout } \\
\text { et al. (2013) (7) }\end{array}$ \\
\hline $\begin{array}{l}\text { Present case } \\
1 \text { male; Antenatal }\end{array}$ & $\begin{array}{l}\text { hemizygous c.2315A- } \\
\text { G missense }\end{array}$ & Exon 16; (p.Lys772Arg) & $\begin{array}{l}\text { probably } \\
\text { damaging }\end{array}$ & deleterious & $\begin{array}{l}\text { Confirmed by } \\
\text { Sanger; identified } \\
\text { the same mutation } \\
\text { in mother }\end{array}$ \\
\hline
\end{tabular}

Table 2-MED 12 mutations reported by other Authors and the present case

\begin{tabular}{|l|l|l|l|}
\hline $\begin{array}{l}\text { DNA } \\
\text { Nucleotide } \\
\text { Change }\end{array}$ & $\begin{array}{l}\text { Predicted } \\
\text { Protein Change }\end{array}$ & Characteristic features & Reference \\
\hline c.2444G>A & p.Arg815Gln & & $(11)$ \\
\hline c.2873G>A & p.Gly958Glu & $\begin{array}{l}\text { Opitz-Kaveggia syndrome } \\
\text { X-linked inheritance } \\
\text { Tall forehead, frontal hair upsweep, long narrow face, open mouth, small } \\
\text { simple ears, absolute or relative macrocephaly, congenital anomalies of } \\
\text { corpus callosum, heart, anus, skeleton, behavioural problems, hypotonia, } \\
\text { constipation, feeding problems }\end{array}$ & $(5)$ \\
\hline c.2881C>T & p.Arg961Trp & $\begin{array}{l}\text { Opitz-Kaveggia syndrome (FG syndrome) } \\
\text { X-linked disorder; multiple congenital anomaly-cognitive impairment } \\
\text { disorder }\end{array}$ & $(4,12)$ \\
\hline
\end{tabular}




\begin{tabular}{|c|c|c|c|}
\hline & & $\begin{array}{l}\text { Mental retardation, relative macrocephaly, hypotonia and constipation. } \\
\text { Family history of deceased male infants, multiple foetal losses } \\
\text { Tall forehead, frontal hair upsweep, long narrow face, open mouth, small } \\
\text { simple ears, absolute or relative macrocephaly, congenital anomalies of } \\
\text { corpus callosum, heart, anus, skeleton, behavioural problems, hypotonia, } \\
\text { constipation, feeding problems }\end{array}$ & \\
\hline c. $3020 A>G$ & p.Asn1007Ser & $\begin{array}{l}\text { Lujan (Lujan-Fryns) syndrome } \\
\text { Tall stature with asthenic habitus, macrocephaly, tall narrow face, } \\
\text { maxillary hypoplasia, high narrow palate, dental crowding, receding chin, } \\
\text { long hands with hyperextensible digits, hypernasal speech, hypotonia, } \\
\text { mild-to-moderate mental retardation, behavioural problems, dysgenesis of } \\
\text { the corpus callosum. } \\
\text { Overlapping features with FG syndrome - dysgenesis of the corpus } \\
\text { callosum, relative macrocephaly, tall forehead, hypotonia, mental } \\
\text { retardation, behavioural disturbances. }\end{array}$ & (6) \\
\hline c. $3067 \mathrm{~A}>\mathrm{G}$ & p.Ile1023 Val & $\begin{array}{l}\text { X-linked recessive intellectual disability syndrome; dysmorphic features } \\
\text { long, narrow face, blepharophimosis }\end{array}$ & (13) \\
\hline c. $3443 \mathrm{G}>\mathrm{A}$ & p.Arg1148His & \multirow{3}{*}{$\begin{array}{l}\text { Ohdo syndrome } \\
\text { Intellectual disability; typical facial features, blepharophimosis. } \\
\text { Short humeri, dysmorphic features, blepharophimosis, Hirschsprung } \\
\text { disease, intellectual disability, hypotonia, behaviour issues, } \\
\text { blepharophimosis, ptosis, facial coarsening, and thick alae nasi }\end{array}$} & \multirow[t]{3}{*}{$(3,7,8,14)$} \\
\hline c.3493T $>C$ & p.Ser1165Pro & & \\
\hline c. $5185 \mathrm{C}>\mathrm{A}$ & p.His1729Asn & & \\
\hline c. $4147 \mathrm{G}>\mathrm{A}$ & p.Ala1383Thr & $\begin{array}{l}\text { Ohdo syndrome } \\
\text { Feeding difficulties, microcephaly, speech delay, hypertonia, eosinophilic } \\
\text { esophagitis, penile chordee, facial dysmorphisms } \\
\text { Represent a new phenotype, reflecting a spectrum of characteristics }\end{array}$ & (15) \\
\hline c.5898dupC & $\begin{array}{l}\text { p.Ser1967GlnfsTe } \\
\text { r84 }\end{array}$ & $\begin{array}{l}\text { FG, Lujan, Ohdo syndrome, the Maat-Kievit-Brunner type, are described } \\
\text { as distinct syndromes with overlapping phenotype and different missense } \\
\text { mutations of the MED12 gene } \\
\text { Long narrow face, high forehead, flat malar area, high nasal bridge, short } \\
\text { philtrum, very limited language, cognitive impairment }\end{array}$ & (16) \\
\hline c. $5922 \mathrm{G}>\mathrm{T}$ & p.Gln1974His & $\begin{array}{l}\text { X-linked intellectual deficiency (XLID) } \\
\text { MED12 gene causes syndromic and nonsyndromic forms of XLID }\end{array}$ & (17) \\
\hline c. $3883 \mathrm{C}>\mathrm{T}$ & p.(Arg1295Cys & $\begin{array}{l}\text { Mild to severe ID, speech delay, behavioural problems, dysmorphic facial } \\
\text { features, hearing loss }\end{array}$ & (18) \\
\hline \multicolumn{2}{|c|}{ Present Case } & Features identified antenatally & $\begin{array}{l}\text { Features } \\
\text { identified } \\
\text { postnatally }\end{array}$ \\
\hline c. $2315 \mathrm{~A}-\mathrm{G}$ & p.Lys772Arg & $\begin{array}{l}\text { Ambiguous genitalia, Syndactyly } 2 \& 3 \text { rd toe, single feet, Early onset } \\
\text { growth retardation, Corpus callosum dysgenesis [Isidor B etal. (2014)] }\end{array}$ & $\begin{array}{l}\text { Penoscrotal } \\
\text { hypospadias, } \\
\text { Blepharophimosi } \\
\text { s, low set ears, } \\
\text { thin vermilion, } \\
\text { long philtrum, } \\
\text { Micrognathia }\end{array}$ \\
\hline
\end{tabular}

Table 3 - Genotype - Phenotype corelation of the MED 12 mutations

Clinical presentation, phenotype and mutational analysis led to provisional diagnosis of possible $M E D 12$ related disorder; $\mathrm{X}$ linked Ohdo syndrome or FG syndrome.

\section{Discussion}

MED12 being a member of large Mediator complex; has a very crucial and central role in RNA polymerase II transcription. It regulates the cell signals involved in growth, development and differentiation.

$\mathrm{MKB}$ is a rare condition; $\mathrm{X}$-linked recessive inheritance; very typical pattern of facial features which are difficult to be detected on antenatally. It is probably the first case of detection of foetal phenotype of MKB.
With ever increasing use of massive parallel sequencing with nextgeneration sequencers, it is likely that more MED12 distinctive phenotype and mutations will be detected. This also helps in identifying the genetic aetiology in families with intellectual disability and dysmorphic features and to broaden genotype-phenotype correlations.

\section{References}

1. Opitz JM, Kaveggia EG. (1974) Studies of malformation syndromes of man 33: the FG syndrome. An X-linked recessive syndrome of multiple congenital anomalies and mental retardation. Z Kinder heilkd 117: 1-18. 
2. Lujan JE, Carlin ME, Lubs HA. (1984) A form of X-linked mental retardation with marfanoid habitus. Am J Med Genet. 17: 311322.

3. Maat-Kievit A, Brunner HG, Maaswinkel-Mooij P. (1993) Two additional cases of the Ohdo blepharophimosis syndrome. Am J Med Genet. 47: 901-906.

4. Risheg H, Graham JM, Clark RD, et al. (2007) A recurrent mutation in MED12 leading to R961W causes Optiz-Kaveggia syndrome. Nat Genet. 39:451-3.

5. Rump P, Niessen RC, Verbruggen KT, et al. (2011) A novel mutation in MED12 causes FG syndrome (Opitz-Kaveggia syndrome). Clin Genet. 79:183-8.

6. Schwartz CE, Tarpey PS, Lubs HA, et al. (2007) The original Lujan syndrome family has a novel missense mutation (p.N1007S) in the MED12 gene. J Med Genet. 44:472-7.

7. Vulto-van Silfhout AT, de Vries BB, van Bon BW, et al. (2013) Mutations in MED12 cause X-linked Ohdo syndrome. Am J Hum Genet. 92:401-6.

8. Isidor B, Lefebvre T, Le Vaillant C, eta 1. (2014) Blepharophimosis, short humeri, developmental delay and hirschsprung disease: expanding the phenotypic spectrum of MED12 mutations. Am J Med Genet A. 164A:1821-5.

9. Adzhubei, I.A., Schmidt, S., Peshkin, L., Ramensky, V.E., Gerasimova, A., et al. (2010) A method and server for predicting damaging missense mutations. Nat. Methods 7, 248-249.

10. Ng, P.C., and Henikoff, S. (2001) Predicting deleterious amino acid substitutions. Genome Res. 11, 863-874

11. Tzschach A, Grasshoff U, Beck-Woedl S, et al. (2015) Nextgeneration sequencing in X-linked intellectual disability. Eur $J$ Hum Genet. 23:1513-8.
12. Clark RD, Graham JM Jr, Friez MJ, et al. (2009) FG syndrome, an X-linked multiple congenital anomaly syndrome: the clinical phenotype and an algorithm for diagnostic testing. Genet Med. 11:769-75.

13. Yamamoto T, Shimojima K. (2015) A novel MED12 mutation associated with nonspecific X-linked intellectual disability. Hum Genome Var. 2:15018.

14. Verloes, A., Bremond-Gignac, D., Isidor, B., et al. (2006) Blepharophimosis-mental retardation (BMR) syndromes: a proposed clinical classification of the so-called Ohdo syndrome, and delineation of two new BMR syndromes, one X-linked and one autosomal recessive. Am. J. Med. Genet. 140A: 1285-1296.

15. Langley KG, Brown J, Gerber RJ, et al. (2015) Beyond Ohdo syndrome: A familial missense mutation broadens the MED12 spectrum. Am J Med Genet A. 167A:3180-5.

16. Lesca G, Moizard MP, Bussy G, et al. (2013) Clinical and neurocognitive characterization of a family with a novel MED12 gene frameshift mutation. Am J Med Genet A. 161A:3063-71.

17. Bouazzi H, Lesca G, Trujillo C, et al. (2015) Nonsyndromic Xlinked intellectual disability in three brothers with a novel MED12 missense mutation. Clin Case Rep. 3:604-9.

18. Rubinato E, Rondeau S, Giuliano F, et al. (2019) MED12 missense mutation in a three-generation family. Clinical characterization of MED12-related disorders and literature review. European Journal of Medical Genetics. 63(3):1037683.

19. Richards, S., Aziz, N., Bale, S. et al. (2015) Standards and guidelines for the interpretation of sequence variants: a joint consensus recommendation of the American College of Medical Genetics and Genomics and the Association for Molecular Pathology. Genet Med. 17, 405-423.

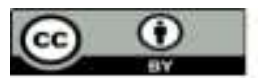

This work is licensed under Creative Commons Attribution 4.0 License

\section{To Submit Your Article Click Here: Submit Manuscript}

DOI: $10.31579 / 2690-8794 / 088$
Ready to submit your research? Choose Auctores and benefit from:

$>$ fast, convenient online submission

$>$ rigorous peer review by experienced research in your field

> rapid publication on acceptance

$>$ authors retain copyrights

$>$ unique DOI for all articles

$>$ immediate, unrestricted online access

At Auctores, research is always in progress.

Learn more auctoresonline.org/journals/clinical-medical-reviews-andreports 